\title{
UPAYA PEMBUKTIAN OTENTISITAS AL-QUR`AN. MELALUI PENDEKATAN SASTRA (TAFSIR ADABIY)
}

\author{
Achmad Zubairin \\ Dosen STAI Asy-Syukriyyah Tangerang \\ zubairin@asy-syukriyyah.ac.id
}

\begin{abstract}
Abstrak
Sampai saat ini al-Qur'an sudah tersusun dengan baik, namun kajian seputar sejarah pengkodifikasian al-Qur'an itu sendiri, masih ada yang mengkaji dan meneliti untuk merekonstruksi sejarah kodifikasi al-Qur`an. Sebagaimana dijelaskan Quraisy shihab tentang materi sejarah Qur`an biasanya menggunakan terminology Jam' Quran, Rasm Quran, Kitabah Quran, Tashhif Quran. Oleh ulama muslim yang diwakili oleh al-anbari (Al-Mashahif),al-sijistani(Kitab al-mashahif),al-abyari (tarikh quran), al-zanjani(tarikh quran) dll. Dari kalangan orientalis diwakili oleh : Noeldeke,Jeffery dan Bell. Dengan pendekatan sastra (tafsir adabiy), dengan seluruh konteks yang membentuk teks al-Qur'an itu sendiri, dengan sendirinya akan menunjukan bahwa al-Qur'an itu otentik.
\end{abstract}

Key Word : otentik, tafsir adabiy, sastra.

\section{ملاخصة}

إن هذاالقرآن يكون مصحفا رسميا مرتبا، لكن البحث حول تاريخ جمع القرآن نفسـه مازال ولم يزل حيّا حتى الآن، ليكشف كل الحادثة التى وقع في ذلك الوقت. كما بيّنـا قريش شهاب أن الكلمة التى تُسنتَعْمَلُ فى هذا البحث هو "جمع القرآن، رسم القرآن، كتابة القرآن، تصحيف القرآن." والمصنَّفات التى تَبْحَثُ عن هذا، منها الأنبري في "المصاحف"، اليّّجستانى في "كتاب المصاحف"، الأبيارى والزنجانى في "تاريخ القران". ومن المستشرقين منها نولديك، جيفرى، وبيل. إن التفسير الأدبي بجميع السياق التاريخي الذى يدور حول النص القرآنى، دليل على أن القران هو كلام الله. 


\section{A. PENDAHULUAN}

Al-Qur'an yang penuh dengan petunjuk, undang-undang, dan hukum, diturunkan sebagai pokok-pokok keterangan yang tidak dapat disangkal kebenarannya. Ia membekali manusia dengan berbagai prinsip dan bermacam-macam kaidah umum serta dasar-dasar ajaran yang menyeluruh. Allah SWT. menegaskan kepada Rasul-Nya Muhammad SAW agar menjelaskan kepada manusia atas segala yang tersirat dalam semua prinsip, kaidah, dan ajaran pokok tersebut secara terperinci, bagian demi bagian, termasuk semua cabang dan rantingnya. ${ }^{1}$

Kitab suci al-Qur'an memiliki kandungan pengetahuan yang luar biasa luasnya, menyangkut aspek kesemestaan, kesejarahan, kemasyarakatan, fisika, dan metafisika. AlQur'an merupakan inspirator bagi pengembangan cabang-cabang ilmu pengetahuan yang menuntut umat manusia untuk menggali dan memahaminya lebih jauh. ${ }^{2}$

Tentu saja, kunci untuk menggali dan memahaminya lebih jauh tentang semua risalah yang terkandung di dalamnya itu adalah melalui jalan penafsiran secara benar dan tepat. Kitabullah yang mulia itu, yang tidak mengandung ketidakbenaran, baik secara terang-terangan maupun samar-samar. ${ }^{3}$

Tuntutan al-Qur'an kepada umat manusia untuk menggali dan memahaminya lebih jauh tersebut, berakibat munculnya para mufassirin terpanggil untuk menafsirkan alQur'an dari sudut pandang yang beragam. Keberagaman penafsiran tersebut disebabkan karena perbedaan metodologi, latar belakang kehidupan sosial, dan kemampuan intelektual mereka pada suatu zaman tertentu.

Kebutuhan kajian Tafsir dengan pendekatan sastra semakin dibutuhkan mengingat berbagai belahan dunia saat yang banyak yang menafsirkan al-Qur'an tanpa memperdulikan redaksional, gramatikal dan nilai kesusasteraan bahasa Arab yang notabene bahasa al-Qur'an. Arti dan tafsir secara asal-asalan ini kemudian memicu banyak

\footnotetext{
${ }^{1}$ Ahmad Asy-Syibani, Sejarah Tafsir Al-Qur'an (Jakarta: Pustaka Pirdaus, 1985) hlm.2

${ }^{2}$ Quraish Shihab, Sejarah dan Ulum Al-Qur'an (Jakarta: Pustaka Pirdaus, 1999) hlm. v

${ }^{3}$ Ahmad Asy-Syibani, Sejarah Tafsir Al-Qur'an .... hlm 3
} 


\section{Jurnal Asy-Syukriyyah}

kesalah-pahaman makna dan tujuan dari Teks suci al-Qur'an bahkan menimbulkan aliranaliran yang sporadis dan dangkal dalam memahami Islam secara umum. Oleh karena itu upaya mengembalikan metode dalam memahami dan menafsirkan al-Qur'an sudah sepatutnya dimulai dari bahasa al-Qur'an itu sendiri yakni bahasa Arab dan segenap kesusasteraannya

\section{B. PEMBAHASAN \\ 1. Sejarah Al-Qur`an}

Beatrice Gruendler berpendapat bahwa seluruh teks arab berasal dari ejaan fenisia. ${ }^{4}$ Argumentasi pendapat ini adalah bahwa banyak ayat dalam Qur`an yang tidak ditemukan maknanya dalam bahasa Arab Quraish ketika itu, melainkan dari ejaan syiriac. Ayat yang menguatkan adalah wa huurun iin, jika diartikan maka ayat ini memiliki makna bidadari yang suci dalam bahasa arab Mekah,

Audiens/mukhathab (yang diajak bicara) ketika al-Qur'an diturunkan adalah bukan masyarakat arab Mekah yang tidak menguasai topic perdebatan filsafat, melainkan diturunkan kepada orang-orang yang menguasai ilmu filsafat yaitu orang-orang yang berdomisili di Mesopotamia (Irak-sekarang). Argumentasi yang mendukung pendapat diatas itu adalah ayat : qul man yuhyiil izhooma wahiya ramiim, qul yuhyiihalladzi ansya aha awwala marrah. Ayat ini mendiskusikan proses pembangkitan manusia kembali setelah kematian.

Pendapat yang sama juga dilontarkan John Wansbrough dimana dia berpendapat bahwa al-Qur'an di turunkan di mesopotamia (Iraq). Argumentasi yang dikemukakan olehnya adalah bahwa audiens yang diajak bicara adalah orang-orang filusuf bukan kafir quraisy mekah.Contoh "qul yuhyihal lazi ansya aha awwala marrah" ini adalah perdebatan Filsafat Plato tentang penghidupan kembali setelah kematian. ${ }^{5}$

\footnotetext{
${ }^{4}$ Beatrice Gruendler, History of qur`anic text, hlm. 134.

${ }^{5}$ John Wansbrough, Quranic Studies Sources and Methods of Scriptural Interpretation,.Oxford University Press 1977.
} 


\section{Jurnal Asy-Syukriyyah}

Dari pandangan Gruendler dan Wansbrough diatas, pertama penulis akan menunjukan Asbab Nuzul dari ayat 78-79 surah Yasin. Sebagaimana yang direkam oleh Al-Suyuthi : dari Ibnu Abbas RA. : telah datang kepada Nabi SAW 'Ashi bin Wa'il kepada Rasulullah SAW dengan membawa sebuah tulang, lalu mematahkannya menjadi dua bagian, kemudian berkata kepada Nabi SAW: Hai Muhammad apakah engkau mampu untuk menyambung lagi tulang yang patah ini setelah aku buang? Nabi SAW menjawab : "Iya, Allah Mampu menyambung tulang yang sudah dipatahkan sebagaimana Dia Mampu Mematikan manusia kemudian dibangkitkan lagi lalu memasukan engkau ke neraka." Lalu turunlah ayat ini. ${ }^{6}$

Dari keterangan Suyuthi tersebut, penulis berpendapat bahwa dialog yang terjadi antara Nabi SAW dan salah seorang badui ini terjadi di kota Mekah/Madinah bukan di negeri lain.

\section{Rekonstruksi Ilmu Asbab Nuzul Dan Ilmu Nasikh-Mansukh}

Sahrur mengkritisi ilmu Asbab Nuzul dan Ilmu Nasikh-Mansukh. Menurutnya, banyak pertanyaan seputar kedua ilmu tersebut. Berikut ini adalah factor yang mengiringi terbentuknya ilmu Nasikh-Mansukh: ${ }^{7}$

a. Tereduksinya arti jihad kepada kontak fisik (perang) dan tereduksinya makna dakwah dengan nasehat kepada dakwah dengan senjata.

b. Penghapusan pemahaman tentang perbuatan seseorang dan balasannya diakhirat, kemudian diganti dengan balasan yang retoris seperti syafaat, karamah, wilayah dll., yang otoritas nya ada ditangan sekelompok pemuka agama saja

c. Doktrinasi konsep keterpaksaan manusia (Jabr), dan penghapusan peran manusia secara total.

d. Penolakan peran akal dan doktrinasi pemahaman pasrah kepada keputusan orang lain.

\footnotetext{
${ }^{6}$ Al-Suyuthi, Asbab Nuzul. hlm. 218.

${ }^{7}$ Muhammad Syahrur, Al-Kitab wal Qur 'an Qiraah Mu'ashirah.
} 


\section{Jurnal Asy-Syukriyyah}

Adapun berikut ini adalah factor yang mengiringi terbentuknya ilmu Asbab Nuzul:

a. Doktrinasi konsep tentang keadilan sahabat Nabi dan kesuciannya('Adalatu sahabah wa ishmatuhum).

b. Diskriminasi salahsatu mazhab atas mazhab lainnya, dan salah seorang sahabat atas sahabat lainnya.

Oleh karena Ilmu Asbab Nuzul menjelaskan tentang konteks pemahaman para sahabat ketika itu, yang belum tentu bisa diterapkan dizaman sekarang.

Penulis memiliki pendapat yang berbeda dari Syahrur tentang makna kata Jihad dalam Qur`an, Menurut Gracia dengan teorinya bahwa ada kata yang berubah/berkembang (al-mutaghayir) maknanya dari makna aslinya, dan ada yang tetap/tidak berubah (atstsabit). ${ }^{8}$ Maka kata Jihad, menurut penulis dengan bantuan teori Gracia, merupakan kata dalam al-Qur'an yang memiliki perubahan makna sesuai dengan kondisi dan waktu kata tersebut digunakan, memang betul ada sebagian penafsir yang menafsirkan dengan perang, hal itu karena penafsir menggunakan kata itu dimana waktu itu masih terjadi peperangan, namun saat ini, dimana tidak terjadi peperangan, maka hemat penulis, kita kembalikan saja ke makna aslinya, sebagaimana tertera dalam kamus-kamus bahasa arab seperti Lisanul Arab yang mengartikannya dengan Al-Juhdu atau kemampuan. ${ }^{9}$

Nasikh-Mansukh menurut penulis bukanlah produk para sahabat sebagaimana pendapat syahrur diatas, tapi al-Qur'an itu sendiri yang menasakh ayat yang lain. Sebagaimana dijelaskan Al-Suyuthi : tentang jenis Naskh yang diakui dalam ilmu alQur`an, yaitu al-Qur'an yang menaskh ayat al-Qur'an yang lain. ${ }^{10}$

\section{Pendekatan Sastra dalam Al-Qur`an.}

Membincang kemukjizatan al-Qur'an memang tak pernah usang. Kali ini dilihat dari sisi sastra (adabiy) nya. Jika dua kemukjizatan dari sisi sain-teknologi (ilmiy) dan York Press.

${ }^{8}$ Jorge J.E. Gracia, A Theory of textuality The Logic and Epistemology, State University of New

${ }^{9}$ Ibnu Manzhur, Lisan Arab, Daru Shadir-Beirut.

${ }^{10}$ Imam Suyuthi, Al-Itqon fii Ulum Qur`an, Majma' Malik Fahd liththiba'ah-Madinah. hlm. 1435. 


\section{Jurnal Asy-Syukriyyah}

social-kemasyarakatan (adab-ijtimaiy) adalah jawaban atas persoalan kontemporer, maka sisi sastra (adabiy) lebih kepada kembali kepada makna teks (nash) dan makna dibalik teks (nash) untuk kemudian digunakan sebagai alat bantu dalam menafsirkan. Misalnya kisah-kisah yang ada dalam al-Qur`an, jika dikaji dengan pendekatan semiotika misalnya, maka seakan-akan kisah-kisah tersebut bukan hanya sebatas legenda dan dongeng sebelum tidur saja, namun memiliki relevansi dengan fenomena yang saat ini sedang terjadi (doblemovement). Atau pada saat ketika ayat al-Qur'an berbicara tentang suatu hokum misalnya,jika dikaji dengan kacamata filsafat hokum (hermeneutika) misalnya, maka akan menghasilkan sebuah kaidah hokum (ushul fikih), dimana produk hokum tersebut lebih sesuai dengan kondisi saat ini (Shalihun lizzamanih).

Tidak heran jika para penafsir dan pengkaji ilmu al-Qur`an, banyak yang meneliti sisi sastra al-Qur'an tersebut, ini tidak lain dikarenakan bahasa yang digunakan al-Qur'an itu sendiri yaitu bahasa arab. Bahasa yang memiliki banyak keistimewaan juga kekayaan kaidah yang terkandung didalamnya. Sebut saja Binti Syathi`, seorang pencetus metode bayani dalam tafsir al-Qur’an, selain pandai dibidang bahasa dan sastra arab, juga menyumbangkan kontribusinya dalam keilmuan al-Qur'an yaitu dengan mengangkat kemukjizatan al-Qur'an ini dari sisi sastra. Dia bersama sang suami yaitu Amin al-Khulli, mengembangan metode bayani ini. Atau Ahmad Muhammad Khalafallah, seorang sarjana muslim yang menjelaskan metode semiotika kisah-kisah dalam al-Qur`an. Dia menjelaskan bagaimana al-Qur'an itu bercerita dengan begitu "hidup"nya, bagaimana sastra al-Qur'an dalam menceritakan setiap kisah yang ada didalamnya dengan nilai sastra yang sangat tinggi.

Disamping tentu saja karya-karya para pendahulu yang kompeten, khususnya dibidang tafsir al-Qur'an dari sisi sastranya, seperti :Al-Zamakhsyariy,dll.

Tidak dapat dipungkiri bahwa sejarah penafsiran al-Qur'an dari masa ke masa mengalami perkembangan yang signifikan. Metode penafsirannya pun kemudian 


\section{Jurnal Asy-Syukriyyah}

bermunculan. ${ }^{11}$ Atau corak penafsirannya pun mengalami perkembangan. Kesemuanya adalah dalam rangka membumikan al-Qur'an di atas bumi ini.

Untuk zaman sekarang ini Amin al-Khulli menjelaskan urgensi al-Qur'an sebagai berikut $^{12}$ : Tujuan yang lebih utama dan lebih penting (selain sebagai petunjuk bagi manusia) adalah menjadikan al-Qur'an sebagai kitab sastra arab terbesar dan mempunyai pengaruh nilai sastra arab terbesar dan melestarikannya. Pendapat ini kemudian diikuti oleh Muhammad Ahmad Khalafallah, Aisyah Abdur Rahman atau Bintu Shati' (w.1998 m.), M. Syukri Ayyad (w. 2000 m.) dan Nasr Hamid Abu Zayd.

Namun sulit untuk dapat menerima pendapat ini karena dilihat dari definisi alQur'an itu sendiri yaitu kitab suci yang diturunkan kepada Nabi Muhamad saw dengan bahasa arab, diturunkan secara mutawatir (peristiwa Nuzul al-Qur`an), dimana membacanya adalah ibadah, dimulai dari surat al-Fatihah dan diakhiri surat al-Nas. ${ }^{13}$ Jelas bahwa al-Qur'an itu sendiri telah mengandung nilai-nilai sastra arab yang tinggi yang mengalahkan sastra-satra arab jahiliyah pada waktu itu dan sangat sulit untuk memisahkannya. ${ }^{14}$

Kaum muslimin saat ini dihadapkan pada hal pemisahan antara wahyu Tuhan dalam al-Quran, dan sesuatu yang dapat dinalar oleh akal manusia yang berobjekan makhluk dengan tetap bersandarkan atas ketetapan Tuhan. ${ }^{15}$ Amin al-Khuli menjelaskan tentang urgensi al-Qur'an sebagai berikut : “Tujuan yang lebih utama dan lebih penting

${ }^{11}$ Abdul Hayy al-Farmawi membagi metode penafsiran al-Qur'an kepada empat: Tahlili, ijmali, muqarin, dan maudhu'i. Lihat Abdul Hayy al-Farmawi, Metode Tafsir Maudu'iy, suatu pengantar, (Jakarta : Rajawali Press, 1994) hlm.11.

${ }^{12}$ Amin al-Khulli, Min A'mal Amin al-Khulli Manahij Tajdid fi al-Nahwi wa al-Balaghati wa alTafsir wa al-Adab, Maktabah al-Usrah 2003 m, hlm. 229

13 Wahbah Zuhaili, Al-Qur'an al-Karim Bunyatuhu al-Syari'iyah wa Khasha ishuhu alHadhariyah, Dar al-Fikr al-Mu'ashir Beirut, cet. I 1993 M. hlm. 9.

${ }^{14}$ Q.S. al-Baqarah $2: 23$

${ }^{15}$ Muhamad Arkoun, Minal Ijtihâd ila Naqdi Aqli Islamiy. 


\section{Jurnal Asy-Syukriyyah}

(selain sebagai petunjuk bagi manusia) adalah menjadikan al-Qur'an sebagai kitab sastra arab terbesar dan mempunyai pengaruh nilai sastra arab terbesar dan melestarikannya." 16

Menurut Toshihiko Izutsu (1914-1993), al-Qur'an adalah ladang subur semantik, yang mencakup beragam kata beserta akar bahasanya, kemudian diintegrasikan kedalam metode penafsiran kontemporer yang berbeda dengan masa sebelum jahiliyah. Menurutnya cara terbaik untuk menguji keotentikan kosakata dalam al-Qur'an adalah dengan cara melihat kondisi turunnya kata tersebut untuk kemudian digunakan disaat yang berbeda sebagai usaha menjawab berbagai pertanyaan yang muncul dengan benar. ${ }^{17}$ Begitu juga halnya dengan Naguib al-Attas : "Penggunaan kosa kata bahasa arab kontemporer (berbeda dengan pre-jahiliyah) dalam al-Qur'an sangat revolusioner dalam catatan sejarah beragama dan perkembangan peradaban bangsa arab, ini ditegaskan dengan transformasi semantik bahasa arab sebagai kata kunci dalam wordview mereka, yang menjadikan Nabi Muhammad mendapat julukan ahli nujum, tukang sihir, dll."18

Ilmu balaghah belum dikenal seperti sekarang ini sampai digunakannya beberapa penamaan, seperti "Kritik atas sya'ir" (Naqd Syi'r), "Sya'ir-sya'ir" (Shun'atus Sya'ir), "Kritik atas prosa" (Naqdul Kalam). Ini terlihat dari sebuah karya yang ditulis Abu Hilal al-Askari yang berjudul "Al-Shină 'ataini” (Prosa dan Puisi), atau dari karyanya Qudamah bin Ja'far yang berjudul “Naqdus Syi'r". Adapun penamaan al-Ma'ani, al-Bayan, al-Badi' merupakan produk ulama masa kini, ini sebagaimana tertera dalam catatan kaki Al-Anbabi halaman 3 pada karyanya "Risălatus Shibbăn" sebagai bentuk salinan dari catatan kaki alSuyuthi atas Tafsir Baidhawi. Dikalangan sahabat sendiri, nama Umar bin Khattab adalah seorang yang paling kritis atas sya'ir di masanya. Demikian pula halnya dengan Ali bin Abi Thalib yang memiliki kata mutiara yang sangat terkenal dikalangan para pujangga waktu itu.

${ }^{16}$ Amin al-Khuli, Min A'mal Amin al-Khuli: Manâhij Tajdid fi al-Nahwi wa al-Balâghati wa alTafsir wa al-Adab. hlm. 229.

${ }^{17}$ Tosihiko Isutzu, Concept of Belief in Islamic Theology: a Semantic Analysis of Iman and Islam, $\operatorname{hlm} .3$

${ }^{18}$ Wan Mohd Nor Wan Daud, The Educational Philosophy and Practice of Syed Muhammad Naquib al-Attas: An Exposition of the Original Concept of Islamization, hlm. 318-19 


\section{Jurnal Asy-Syukriyyah}

Pada masa dinasti Umayyah, melestarikan bahasa arab dan sastranya merupakan suatu keharusan guna mengukuhkan legitimasi politik pemerintahannya, maka dari itu banyak sastrawan terkemuka yang muncul di masa ini dalam rangka menghadapi musuhmusuh mereka yang mencoba melemahkan roda kepemimpinan dinasti ini.

Upaya memperbaiki metodologi dalam ilmu balaghah setidaknya terlihat dari munculnya karya-karya para sastrawan muslim, diantaranya : "al-Ma'ăni" karya Al-Sadusi (2-3 h.), "al-Fashăhah" karya Abi Hatim al-Sijistaniy (w.200 h.), "al-Balăghah” karya AlMubarrid (w.283 h.). Dalam ilmu Bayan karya yang pertama kali muncul adalah "Majăzul Qur`an” karya Abu Ubaidah Muammar bin al-Mustanna (w.211 h.), dalam ilmu Badi' yaitu "Kitabul Badı̌”" karya Abdullah bin al-Mu'taz (w.302 h.) ${ }^{19}$

Menurut Hana al-Fakhuri dalam karyanya "Tarikh al-Adab al-Arabiyyah", Dalam Dinasti Abbasiah, terjadi periodesasi sastra ke dalam tiga periode : Periode Pertama : Diawali dengan Basyar bin Burdin dan diakhiri dengan Abu Tamam yang dikenal dengan "Sastra reformis" (Adab Quwwah Tajdidiyah). Diantara sastrawan yang muncul pada masa ini adalah : Abu Nawas (145-198 h.), Abul 'Atahiyah (130-210 h.), Muslim bin al-Walid (130-208 h.) Hasan bin Dhahak (162-250 h.). Periode Kedua : Diawali dari Abu Tamam (180-228 h.) diakhiri dengan al-Mutanabbi atau lebih dikenal dengan "Sastra pergerakan revolusioner" (Adabul Harakah Mu'akisah). Diantara sastrawan yang muncul ialah alBuhtari, Ibnu Rumi, Ibnul Mu'tazz . Periode Ketiga : Diawali dengan al-Mutanabbi dan diakhiri oleh al-Baha`Zuhair (581-656 h.) atau yang dikenal dengan "Sastra modern" (Adabul Istiqrar Watadarruj). Diantara sastrawan yang terkemuka adalah Abu Faras alHamdani, Syarif Ridha, Abul A'la al-Mu'tari.

Mazhab dalam ilmu Nahwu (Mazhab Kufah dah mazhab Bashrah) pun banyak yang berasal dari al-Qur`an. Ini sekaligus membantah pernyataan Syaikh Adhimah dan juga Montgomeri Watt yang menjelaskan bahwa dalam al-Qur'an banyak ditemukan berbagai kerancuan yang menyebabkan al-Qur'an dan ilmu nahwu saling bertentangan.

${ }^{19}$ Amin al-Khuli, Min A'mal Amin al-Khuli: Manâhij Tajdid fi al-Nahwi wa al-Balâghati wa alTafsir wa al-Adab. hlm. 82. 


\section{Jurnal Asy-Syukriyyah}

Adalah Imam al-Ghazali sebagai seorang sufi yang sekaligus penyair, yang di masa-masa awalnya banyak menggunakan puisi (Syi’ir) sebelum menggunakan prosa (Nazham). Sebagaimana terlihat dari puisi yang ia tulis :

- Alangkah malangnya jiwa ini yang banyak berkeluh kesah kepada makhluk. Sedang jiwa itu selalu mengharapkan Allah.

- Sungguh keluh-kesah merusak keikhlasan. Keluh-kesah itulah yang ia banggakan dan harapkan.

- Padahal ia lebih dekat kepada Pemilik-nya, namun ia justru menjerumuskan ke dalam kehinaan.

Ini menunjukan bahwa dalam diri penya'ir itu sendiri banyak berlandaskan ajaran-ajaran islam. $^{20}$

Berkaitan dengan sastra dan budaya arab, menurut Abid Jabiri adalah kumpulan peninggalan klasik yang sampai kepada masyarakat hasil dari reduksi kebudayaan islam pada abad pertengahan. ${ }^{21}$ Ada keterkaitan antara bahasa dan pemikiran, khususnya dalam kebudayaan arab, namun bukan dalam hal epistimologi saja, tapi dalam dasar-dasar pengetahuan yang ada pada kebudayaan tersebut.

Setidaknya ada empat hal yang menunjukan hubungan antara bahasa dan budaya :

- Pertama : Materi bahasa dimana proses periwayatan bahasa berubah menjadi suatu hasil produksi, seperti yang dilakukan oleh Amr bin al-Ala` (w.154 h.), Hammad alRiwayah (w.155 h.), Khalil bin Ahmad (w.170 h.).

- Kedua : Reduksi kaidah Nahwu dan Mantiq yaitu peranan para ahli bahasa dan logika dalam memodifikasi ratio yang menyebabkan lahirnya peradaban bahasa.

- Ketiga : Ungkapan al-bayan al-arabiy dan petunjuk-petunjuknya yaitu terbentuknya ilmu balaghah sebagaimana terbentuknya ilmu-ilmu lainnya berdasarkan kebutuhan dari dalam kebudayaan tersebut atau faktor internal bukan dari faktor eksternal.

- Keempat : Riset ilmu pengetahuan berdasarkan perangkat kecerdasannya (bahasa arab). Malik bin Nabi (Pemikir Muslim Kontemporer asal Aljazair) berpendapat bahwa “Tidak seorang muslim pun dewasa ini -lebih-lebih yang bukan dari Negara-negara

\footnotetext{
${ }^{20}$ Maktab al-Alamiy lil Buhust, Al-Hubb Indal Arab, hlm. 73.

${ }^{21}$ Muhammad Abid al-Jabiri, al-Turast wal Haddâtsah, Dirasah wa Munaqasah.
} 
berbahasa Arab- yang dapat memahami kemukjizatan al-Qur'an dengan membandingkan satu ayat dengan sepenggal kalimat berbentuk prosa dan puisi pra-Islam.”

Untuk memahami kemukjizatan al-Qur'an adalah dengan bermacam-macam cara, salah satunya yaitu dengan memahami teks dan konteks diturunkannya al-Qur`an. Dalam mengapresiasi sastra al-Qur'an, setidaknya kita membutuhkan dua bekal: Pertama, penguasaan bahasa Arab untuk bisa memahami makna ayat-ayatnya. Kedua, ketajaman dan sensitivitas perasaan. Tamsil merupakan bagian dari keistimewaan al-Qur`an, namun tidak semua orang dapat memahami keistimewaan tersebut.

Para penafsir menggunakan bermacam-macam metode dalam menafsirkan ayatayat perumpamaan (Tamsil), misalnya Zamakhsyari dalam Tafsir Kasyaf -nya adalah dengan cara-cara sebagai berikut :

a) Pendekatan munasabat

b) Menjelaskan matsal, dengan memperhatikan hal-hal berikut ini :

1) Pemakaian matsal adalah hal yang populer.

2) Pemakaian matsal adalah dalam rangka memperjelas suatu ayat.

c) Menjelaskan maksudnya secara leksial dan terminologi.

d) Menjelaskan kosakata.

e) Menafsirkan dalam bentuk andaian dan tanya jawab, masalah yang berkaitan dengan sintaksis (ilmu tanzhim).

f) Pembahasan uslub : Tasybih, Isti'arah, Majaz.

g) Nahwu dan Sharaf.

h) Qira`at.

i) Menjelaskan dengan syair jahiliy.

j) Asbabun Nuzul.

Sedangkan Aisyah Abdurrahman binti Syathi menggunakan metode bayani dalam menafsirkan ayat-ayat al-Qur'an yang berkaitan dengan semantik, sebagaimana kita dapati penafsirannya dalam surat al-Zilzalah : "Adalah sangat jelas unsur bayani dalam surat ini, didalamnya terdapat pengulangan kata, dimana pengulangan kata semestinya ada dalam Ithnăb (Ungkapan yang panjang maksudnya singkat), akan tetapi pada ayat ini ditempatkan 


\section{Jurnal Asy-Syukriyyah}

dalam Ijjăz (Ungkapan yang ringkas maksudnya panjang), dan ini merupakan sesuatu yang menarik untuk diperhatikan. Dalam surat al-Zilzalah ini, terjadi delapan kali pengulangan. Pengulangan kata dalam $\hat{I} j a ̆ z$ inilah yang sering digunakan dalam al-Qur'an sebagai ungkapan yang tidak terkalahkan..." "al-Qur'an juga menggunakan bentuk majhul (tidak terlihat subjek/fa'ilnya) dalam menjelaskan suatu kejadian yang sangat dahsyat sebagai bentuk Îjaz." "Idzăzulzilatil ardhu zilzalahă.",22

Perdebatan ini direkam oleh Nasr Hamid Abu Zayd dalam sebuah wawancara berikut :

"Pembahasan masalah al-Qur'an akan kembali ke abad ketiga hijriah, saat kekuasaan politik ikut campur dalam tarik ulur pemikiran soal penciptaan al-Quran. Ma'mun, Khalifah Abbasiah yang pertama ikut campur tangan dan berusaha memaksakan ide penciptaan al-Qur'an dengan menggunakan kekuasaan yang berada di tangannya. Siapa saja yang tidak setuju dengan ide ini bakal disiksa olehnya. Setelah itu, Mutawakkil ikut campur tangan, namun ia membela ide sebaliknya dan Mu'tazilah yang mengakui penciptaan al-Qur'an berbalik mendapat siksaan dari penguasa. Sejak zaman dikeluarkannya perintah dan peraturan dari Mutawakkil tentang akidah Ahli Sunnah yang meyakini al-Qur'an azali dan qadim, masalah ini dalam bentuknya yang jumud berdasarkan akidah Asy'ari-Hambali diwariskan hingga sekarang, sampai masa kebangkitan dan reformasi."

Nasr Hamid Abu Zayd dalam karyanya Mafhŭm Nash menyatakan dengan tegas arti Teks : "Mempelajari teks sebagai teks bahasa maksudnya dimulai dari proses terbentuknya, rangkaian katanya, dilalahnya, hubungannya dengan teks lainnya dalam kebudayaan tertentu adalah suatu kajian dalam hal sastra di era modern. Suatu nash sangat mungkin menjadi bahan kajian dalam ilmu lainnya, atau mungkin menjadi suatu materi dalam kajian bahasa itu sendiri dengan beragam cabang keilmuannya seperti ilmu suara, ilmu dilalah dan kamus. ${ }^{23}$

Definisi tersebut sama seperti pengertian yang dijelaskan Hasan Hanafi dalam karyanya "Minal Naqli ilal Ibda" : Teks dimaknai sebagai rangkaian proses terbentuknya

\footnotetext{
${ }^{22}$ Aisyah Aburrahman Binti Syathi', Al-Tafsirul Bayâni lil Qurânil Karim, hlm. 80

${ }^{23}$ Nasr Hamid Abu Zayd, Mafhŭmun Nash Dirâsah fi Ulŭmil Qur ân, hlm. 18
} 
teks tersebut secara menyeluruh, yaitu seluruh pembahasan teks tersebut, pembahasan babnya, pasalnya, baitnya atau ungkapannya. Teks tidak hanya berisi tentang informasi saja, namun juga merupakan isi dari pembahasan tersebut. Teks merupakan bagian dari sastra (Genre Literaire), dimana diterapkannya sebuah kritik atas sastra, tidak sekedar dokumentasi sejarah, sumber sejarah atau otentisitas sejarah saja. ${ }^{24}$

Berbeda halnya dengan Abdullah Saed, menurutnya makna dalam al-Qur'an sangat berkaitan erat dengan bentuk teks al-Qur`an, oleh karena itu ia membagi teks ke dalam beberapa bentuk. ${ }^{25}$

\section{KESIMPULAN}

Perubahan adalah sebuah keniscayaan dalam kehidupan, dan kemajuan adalah syarat bagi sebuah peradaban, transformasi sosial adalah aturan di masyarakat. Begitu pula halnya dengan penafsiran. Khususnya dalam penafsiran kontemporer (modern). Perdebatan seputar penafsiran kontekstualpun pada hakikatnya telah ada pada tahun 1960-an, ketika Gadamer mewacanakan tentang pengujian suatu penafsiran, yaitu tentang penafsiran suatu karya seni beserta literatur-literaturnya, atau tentang apakah pengetahuan seputar keilmuan-keilmuan sosial adalah objektif, atau tentang fungsi menghubungkan antara disiplin ilmu teologi dengan hukum, atau tentang evaluasi seputar filsafat itu sendiri.

Di penutup tulisan ini, penulis berpandangan bahwa segala karya peneliti alQur`an, baik dari kalangan sarjana muslim atau non-muslim sekalipun semua adalah dalam rangka menjadikan al-Qur'an relevan di setiap ruang dan waktu. Dan kami sangat menyakini bahwa perdebatan seputar al-Qur'an adalah sebagai pengembangan jika tidak dikatakan kemunduran kajian seputar Ilmu Tafsir dan Ilmu-ilmu al-Qur`an.

${ }^{24}$ Hasan Hanafi, Minan Naqli ilal Ibda'. hlm. 46.

${ }^{25}$ A.Saed, Interpreting the Qur'an : toward a contemprory approach, hlm. 90 


\section{DAFTAR PUSTAKA}

Abid al-Jabiri Muhammad, al-Turast wal Haddâtsah, Dirasah wa Munaqasah.

al-Attas: An Exposition of the Original Concept of Islamization

al-Farmawi Abdul Hayy, Metode Tafsir Maudu'iy, suatu pengantar, (Jakarta : Rajawali Press, 1994) .

Al-Suyuthi, Asbab Nuzul.

al-Khulli Amin, Min A'mal Amin al-Khulli Manahij Tajdid fi al-Nahwi wa al-Balaghati wa al-Tafsir wa al-Adab, Maktabah al-Usrah $2003 \mathrm{~m}$.

Arkoun Muhamad, Minal Ijtihâd ila Naqdi Aqli Islamiy.

Abu Zayd Nasr Hamid, Mafhŭmun Nash Dirâsah fi Ulŭmil Qur 'ân.

Binti Syathi`Aisyah Aburrahman, Al-Tafsirul Bayâni lil Qurânil Karim.

Gruendler Beatrice, History of qur`anic text.

Gracia Jorge J.E., A Theory of textuality The Logic and Epistemology, State University of New York Press.

Hanafi Hasan, Minan Naqli ilal Ibda'.

Ibnu Manzhur, Lisan Arab, Daru Shadir-Beirut.

Imam Suyuthi, Al-Itqon fii Ulum Qur`an, Majma’ Malik Fahd liththiba'ah-Madinah.

Isutzu Tosihiko, Concept of Belief in Islamic Theology: a Semantic Analysis of Iman and Islam.

Saed Abdullah, Interpreting the Qur'an: toward a contemprory approach.

Syahrur Muhammad, Al-Kitab wal Qur'an Qiraah Mu'ashirah.

Wansbrough John, Quranic Studies Sources and Methods of Scriptural

Interpretation,.Oxford University Press 1977. 


\section{Jurnal Asy-Syukriyyah}

Wan Daud Wan Mohd Nor, The Educational Philosophy and Practice of Syed Muhammad Naquib

Zuhaili Wahbah, Al-Qur'an al-Karim Bunyatuhu al-Syari'iyah wa Khasha ishuhu alHadhariyah, Dar al-Fikr al-Mu'ashir Beirut, cet. I 1993 M. 